question of whether it should be clinically relieved with aspirin. And does the loss of thermoregulatory control during REM sleep offer any insights into how human brains can be cooled without damage?

The book is entertainingly written, and touches on many issues of general interest. It would certainly capture the attention of biologists and medical practitioners, although, given the detailed accounts of neuronal structures, I doubt that it would be accessible to non-life scientists, despite the authors' intentions. Issues in human neuroscience are authoritatively covered, but the more comparative discussions of thermal biology and the evolution of homeothermy in mammals are less convincing. For example, the idea that vertebrate brains must be warm in order to function effectively does not accord with fish that live in cold, even polar, waters. Indeed, fish can display quite sophisticated thermoregulatory behaviour, as was shown more than 30 years ago, when goldfish trained to control water heaters by leverpressing were able to regulate the temperature to within $1^{\circ} \mathrm{C}$.

Andrew R. Cossins is at the School of Biological Sciences, University of Liverpool, Derby Building, Liverpool L69 3BX, UK.

\section{Catch as catch can?}

Fish, Markets, and Fishermen: The Economics of Overfishing

by Suzanne Iudicello, Michael Weber \& Robert Wieland

Earthscan/Island Press: 1999. 192 pp.

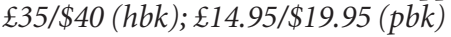

\section{John Godfrey}

Fish in the open sea are a resource common to all, but it does not pay any individual fisherman to hold back from overexploiting it. Indeed, if fish are becoming scarce, then fishing harder will often be the optimum shortterm strategy. It is rational to overfish; this is 'the tragedy of the commons'. What is needed, if we are to avoid the tragedy, is common management, fairly enforced, so that the maximum yield that each population of fish can sustain indefinitely is never exceeded.

How to do this is far from obvious. Fishing policies of governments around the world have responded to pressure from fishermen, often to the detriment of the longer term. Overfishing brings short supply and high prices, to the disadvantage of the poor, for whom fish has historically been a source of cheap first-class protein. But consumers have little influence on policies, because their interest in conservation lacks the immediate impact that policies have on fishermen, and because they lack detailed knowledge. Their

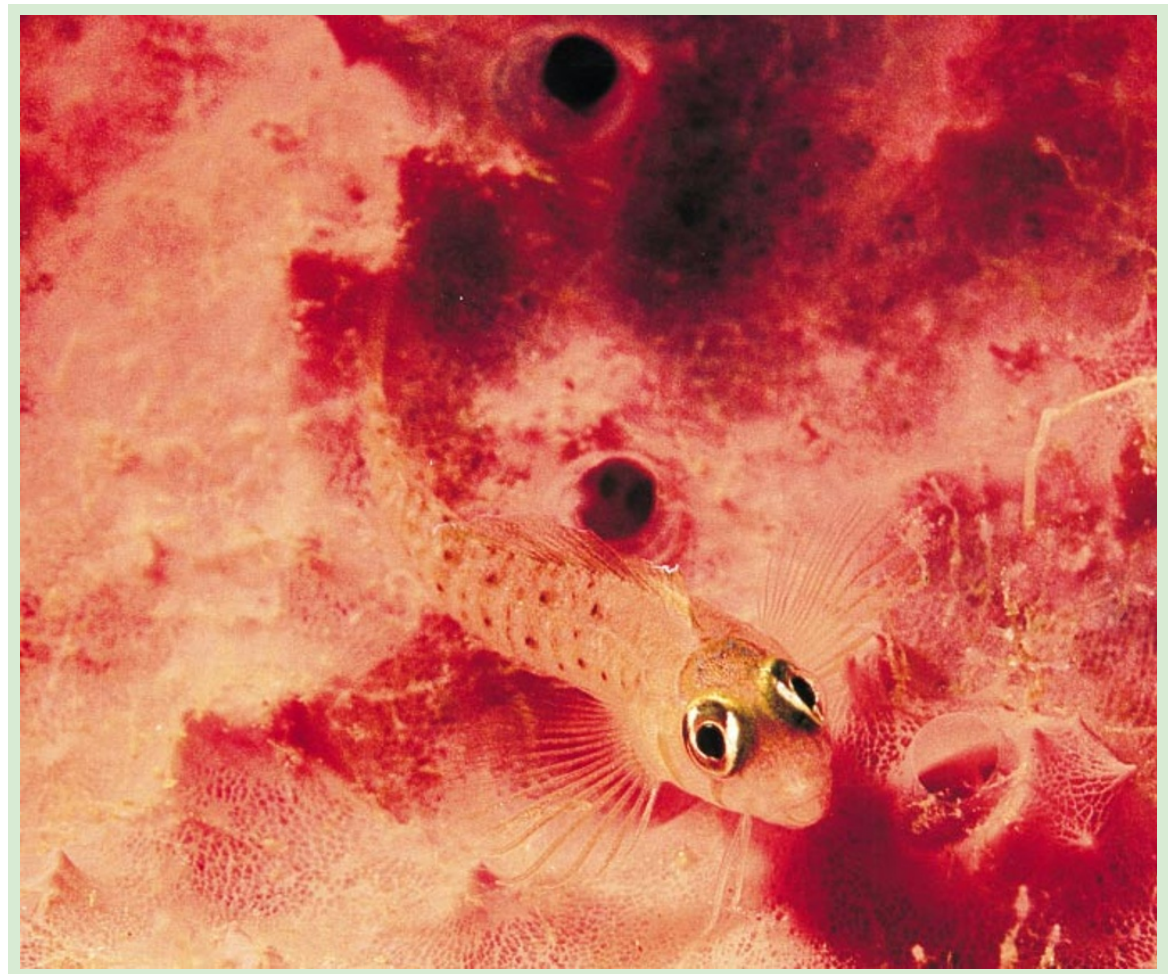

\title{
Views of an underworld
}

The three oceans that surround New Zealand are home to a vast array of exotic marine life, including the Yaldwyn's triplefin (Notoclinops yaldwyni) show above, resting on pink sponge.
Underwater Wonders of New Zealand by Gillian and Darryl Torckler (New Holland, $\mathfrak{E} 19.99$, $\$ 32.95)$ is a lavishly illustrated guide to this underworld. need, in both the short and long term, is sustainable management. The catching industry shares the same goal, but only in the long term.

Iudicello et al. bring a breath of fresh air to the often-stale fish dispute. They show how the exploitation of a new fish stock goes through clear phases: as the effort put into catching the fish increases steadily, the value of the catch grows quickly until the maximum economic yield is reached. There is then the greatest difference between the cost of fishing and the value of the catch. After this, profits fall off until fishing reduces the capacity of the stock to replenish itself. Beyond this, the population will fall and may crash. Policies for fishing should keep fish populations between the maximum economic and the maximum biological yield that can be sustained.

The book goes on to review examples of different management policies for various fish stocks around the world. Most have failed, often because governments give subsidies when fishing communities suffer as fishing becomes uneconomic. This lures back fishermen who might have left a depleted and uneconomic fishery.

The authors shy away from clear recommendations. But their valuable case studies suggest that somehow making fishing private property could be the answer. New Zealand has given individual quotas for fish catches that can then be traded. But the tendency then is for the quotas to be bought up by a few big enterprises. Fishing has historically been a small-scale industry, with the benefits of fishing dispersed among communities with few alternative economic possibilities. If individual quotas were to revert to a regional management body, this difficulty could be avoided and the public interest taken into account.

Because the most productive waters are often fairly near to shore, the universal adoption of 200-mile Exclusive Economic Zones made rational and legally enforceable management possible. The European Union has pooled its EEZs, and although its common fisheries policy ought to be the most successful policy for Europe, it is not. For instance, one year's better recruitment to the cod stocks in the North Sea triggered a larger total allowable catch. The young cohort should instead have been allowed to grow and breed. But the Norwegians, not being members of the European Union and therefore unhampered by the common fisheries policy, have achieved a remarkable recovery of their overexploited cod. Another aspect is the fact that the water in the North Sea has become warmer, and less favourable to breeding by cod, so that greater care in management is needed.

The main failures of management have 
been because the member states in the Council of Ministers so frequently water down the scientific advice they are given. The Treaty of Union requires that the common fisheries policy be reviewed in 2002, and this offers a golden opportunity for a radically improved policy. The European Commission will be producing a discussion document later this year. Fish, Markets, and Fishermen should help to stimulate fresh thinking on how to conserve fish better, for fishermen and consumers alike.

The open ocean presents an even more difficult problem, which is not seriously addressed in the book. Deep-sea fish live in cold water with sparse food supplies, and so grow and breed slowly. Although there are substantial standing stocks, they are particularly susceptible to overexploitation. As the boats and gear for catching them have required larger investments, there is strong motivation to overfish. And there is no sign that the Law of the Sea Convention will act soon enough.

John Godfrey, a member of the European Commission's Advisory Committee on Fisheries, is at 41 Lawford Road, London NW5 2LG, UK.

\section{More on fishing}

Fishing Grounds: Defining a New

Era for American Fisheries

\section{Management}

by the H. John Heinz III Center for Science, Economics and the Environment Island Press, \$27, £25 (pbk)

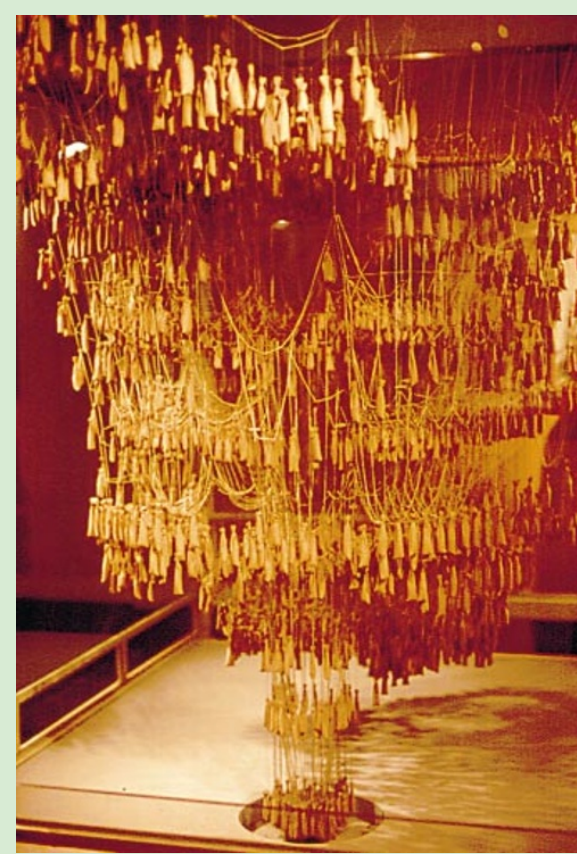

\section{Science in culture}

\section{Inverted logic}

Antoni Gaudí's structural skeletons for

Catalan churches.

Martin Kemp

It is something of a cliché to say that great thinkers can take an idea and turn it on its head in the search for new perspectives. But few can have done so as literally as the astonishing Catalan architect Antoni Gaudí, who designed a series of remarkable secular and ecclesiastical buildings in Barcelona in the early years of the twentieth century.

In common with adventurous architects across Europe, Gaudí was striving to create a form of design that was genuinely new — called art nouveau in France and modernism in Catalonia - yet deeply rooted in the past. Typically, designer-artists looked to styles that were local and indigenous, in Gaudís case the medieval architecture of Catalonia and Spain's striking Moorish heritage. The intention was not so much the kind of eclectic imitation common in the nineteenth century as the extraction of underlying principles of form and structure.

To achieve this deeper penetration, a number of European designers were returning to what they considered to be first principles in the geometrical engineering of organic structures. Gaudí was convinced that the clustered piers and soaring vaults of a Gothic cathedral were closer to nature's living forms than the rectilinear geometry of classical columns and cornices.

In this pan-European quest for nature's geometry, Gaudí was inspired to research the complex geometry of surfaces, such as circular and hyperbolic paraboloids, so that he could construct intersecting combinations of convex and concave shapes that were rigorously geometrical and yet seemed true to nature.

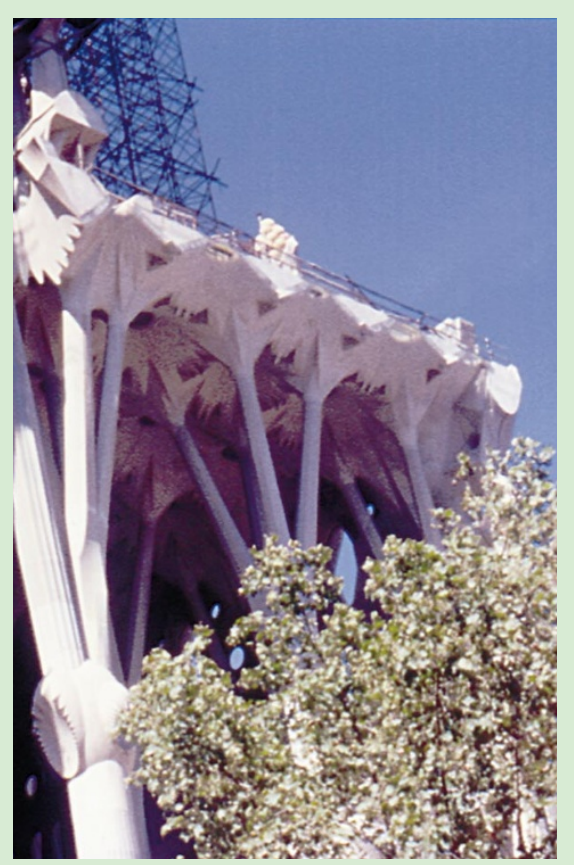

When he translated this geometry into structural practice, his most original act was to re-characterize the arch according to the tenets of 'natural engineering. He took as his model the catenary curve, formed when a chain hangs in a loop from two points. He deduced that the forces of tension in the catenary curve must be resolved along the line of the curve itself. If inverted as a 'catenary arch', the reverse forces of compression should run through the masonry of the arch, without causing the severe outward thrusts that generally necessitated the massive piers or flanking buttresses in large Gothic buildings.

Extrapolating this upside-down design method to cope with complex ecclesiastical buildings, Gaudí plotted their spatial structure through an intricate cobweb of wires and looped strings hanging from points on the scaled ground-plan of the projected building. Small, weighted sacks suspended from the lowest points of the string loops simulated, in reverse, the weight of the intricately curved vaults that were to be suspended between the skeleton of ribs.

Gaudís towering Expiatory Temple of the Sagrada Familia was begun in 1883 and was still piously under construction 74 years after his death. The remarkable hanging models he made for the temple and for his Chapel of the Colònia Güell (1905-15) no longer survive. But a reconstruction of the model for the chapel can now be seen in the museum attached to the unfinished temple (see figure). On such frameworks, duly inverted, Gaudí worked his plastic variations on organic morphologies. His aspiration was that the building should appear to the worshipper as a force of nature itself, a spiritual distillation of God's perfect engineering and design, rather than a mere container made by human agency.

In Barcelona today, Gaudi's legacy and the desirability of finishing his Sagrada Familia are disputed by politico-religious factions in a way that ironically mirrors the architect's own journey from artistic radical to religious conservative. From an international perspective, we can see how he was one of the most original and profound advocates of reforming architectural design in the light of the timeless example of nature.

Martin Kemp is in the Department of the History of Art, University of Oxford, 59 George Street, Oxford OX1 2BE, UK.

Martin Kemp will be giving a talk, "not science AND art", at the Victoria \& Albert Museum, London, on 3 November (7 pm).

Left, vaults of the Sagrada Familia. Far left, Gaudí's hanging model (reconstructed) for the Chapel of the Colònia Güell (Gaudí Museum at the Sagrada Familia, Barcelona). 